\title{
Aspectos de interesse odontolegal observados nas perícias de identificação humana realizadas no Instituto Médico Legal de São Paulo nos anos de 1999 e 2000
}

\author{
Aspects of legal dentistry focus in the human identification \\ inspections performed in the Legal Medical Center \\ of São Paulo during 1999 and 2000
}

\author{
Eduardo de Menezes GOMES ${ }^{1}$
}

GOMES, E. de M. Aspectos de interesse odontolegal observados nas perícias de identificação humana realizadas no Instituto Médico Legal de São Paulo nos anos de 1999 e 2000. Dissertação (mestrado) - Programa PósGraduação em Odontologia. Área de Concentração: Deodontologia e Odontologia Legal. — Faculdade de Odontologia da Universidade de São Paulo. Saúde, Ética \& Justiça, 5/7(1-2):48-9, 2000-2002. [Resumo]

Resumo: O presente trabalho procurou analisar os resultados das perícia odontolegais voltadas à identificação humana realizadas pelo Núcleo de Odontologia Legal do Instituto Médico Legal de São Paulo nos anos de 1999 e 2000. Foram examinados os relatórios emitidos por esse Núcleo, e avaliadas a sua freqüência, a sua origem geográfica e a sua natureza sob a ótica policial. No período estudado foram realizadas 53 perícias dessa ordem, 18 (33,96\%) em 1999 e 35 (66,04\%) em 2000, com predominância de casos provenientes da Capital de São Paulo (66,6\% em 99 e 60\% em 2000). Os homicídios $(61,11 \%$ em 1999$)$ e os encontros de ossadas (60\% em 2000$)$ foram os fatores que mais freqüentemente provocaram a requisição desse tipo de exame. Também foram avaliados os percentuais de casos que demandaram as duas modalidades de perícias identificatórias: as perícias de ordem individual responderam por $41,05 \%$ do total, e aquelas de ordem geral corresponderam a $58,5 \%$ da casuística estudada. Com relação ao tipo de material biológico encaminhado ao Núcleo de Odontologia Legal, houve predominância de crânios $(49,06 \%)$ nos dois anos aqui examinados. As perícias que atingiram resultados conclusivos ( $83,33 \%$ em 1999 e $81,25 \%$ em 2000) reforçam a importância que a documentação odontológica tem nos casos de identificação humana, e indicam que as radiografias são o tipo de documentação de eleição para a resolução de casos dessa ordem. A análise dos casos inconclusivos (16,67\% em 1999 e 18,75\% em 2000) indica que a real causa do insucesso dos exames odontolegais de identificação humana pode ser atribuída à falta de informações odontológicas,

1. Aluno do Programa Pós-Graduação em Odontologia (Mestrado). Área de Concentração: Deodontologia e Odontologia Legal. - Faculdade de Odontologia da Universidade de São Paulo. 
GOMES, E. de M. Aspectos de interesse odontolegal observados nas perícias.

como fichas clínicas incompletas ou prontuários deficientes. Assim, o cirurgião- dentista deve privilegiar, em Sua rotina profissional, a manutenção dos prontuários - com toda a documentação pertinente - que possibilitem não apenas a sua defesa em casos de processos movidos por pacientes, como a identificação de seus pacientes quando vitimados pelas contingências da vida urbana: assassinatos, acidentes aéreos, acidentes automobilísticos, catástrofes etc.

Unitermos: Prova pericial/legislação \& jurisprudência. Odontologia legal/legislação \& jurisprudência. Registros odontológicos. Antropologia forense.

GOMES, E. de M. Aspects of legal dentistry focus in the human identification inspections performed in the Legal Medical Center of São Paulo during 1999 and 2000 Dissertação (mestrado) - Programa Pós-Graduação em Odontologia. Área de Concentração: Deodontologia e Odontologia Legal. - Faculdade de Odontologia da Universidade de São Paulo. Saúde, Ética \& Justiça, 5/7(1-2):48-9, 2000-2002. [Abstracts]

Abstracts: The present work aimed the analysis of the results of the legal dentistry inspections designed to human identification performed in the Legal Dentistry Nuclei of the Legal Medical Center of São Paulo within the years 1999 and 2000. The reports released by this Nuclei were examined and, had its frequency, its geographical origin and specification evaluated under the police official point of view. During the studied period, 53 inspections of this sort were performed, 18 (33.96\%) in 1999 and 35 $(66.04 \%)$ in 2000 where, the cases coming from the Capital (66.6\% in 1999 and, 60\% in 2000) were more predominant. The homicides $(61.11 \%$ in 1999) and the findings of banes $(60 \%$ in 2000$)$ were the factors that more frequently caused the request for this of exams. We also evaluated the percentage of the cases which demanded the both modes of identification inspection: the ones of individual kind amounted $41.05 \%$ of the totais and, those of general kind were $58.5 \%$ of the cases studied. In relation to the biological material sent to the Legal Dentistry
Nuclei, there was a predominance of skulls (49.06\%) within both years of examination. The inspections which reached a matching result $183.33 \%$ in 1999 and $81.25 \%$ in 2000) strengthen the importance that an odontological documentation holds in cases of human identification, and also indicate radiographies are the nominated documents for solving these kinds of cases. An analysis of the non-matching cases (16.67\% in 1999 and $18.75 \%$ in 2000) indicate that the main cause for the failure of the legal dentistry exams for human identification can be set to the lack of odontological information such as, incomplete clinical file cards and inefficient status forms. Thus, the dental surgeon must at first instance, in his professional routine, assure the maintenc: nce of the status forms data - including ali the relating documents - which will make possible not only his defense in case of a trial put on by a patient, as well as the identification of his patients who might be victims of the urban life misfortunes: murders, aerial accidents, car accidents, catastrophes, etc.

Keywords: Expert testimony/legislation \& jurisprudence. Forensic dentistry/legislation \& jurisprudence. Dental records. Forensic anthropology. 